\title{
New scale insects (Homoptera: Coccinea) from the Cape Floristic Region
}

\author{
Ilya A. GAVRILOV-ZIMIN ${ }^{1, *} \&$ Philipp E. CHETVERIKOV ${ }^{2}$ \\ ${ }^{1}$ Zoological Institute, Russian Academy of Sciences, 1 Universitetskaya Emb., \\ St. Petersburg, 199034, Russia. \\ ${ }^{2}$ Saint-Petersburg State University, Universitetskaya nab., 7/9, 199034, St. Petersburg, Russia. \\ *corresponding author: coccids@gmail.com \\ ${ }^{2}$ Email: f.chetverikov@spbu.ru
}

urn:1sid:zoobank.org:author:301C6A0B-C4F4-435A-AE84-350CB7EC44C6

urn:1sid:zoobank.org:author:5440CD2C-D234-416F-A4E8-EFC242F80F1A

\begin{abstract}
Three new scale insect species, Coccidohystrix daedalea Gavrilov-Zimin sp. nov., Mirococcopsis ptilura Gavrilov-Zimin sp. nov. (both from the family Pseudococcidae) and Cryptinglisia millari Gavrilov-Zimin sp. nov. (family Coccidae), are described and illustrated from the Western Cape Province of South Africa.
\end{abstract}

Key words. Scale insects, mealybugs, soft scales, morphology, new species.

Gavrilov-Zimin I.A. \& Chetverikov Ph.E. 2017. New scale insects (Homoptera: Coccinea) from the Cape Floristic Region. European Journal of Taxonomy 366: 1-11. https://doi.org/10.5852/ejt.2017.366

\section{Introduction}

Scale insects are sap-sucking plant parasites which comprise about 8000 nominal species and are known from all biogeographical regions. South Africa and especially the Cape Floristic Region are characterized by an enormously rich and comparatively well studied fauna of scale insects, with more than 500 species from 11 families (see compilative database ScaleNet: García Morales et al. 2016). A series of special papers on scale insects of this region was published by Brain $(1915,1918,1919,1920 \mathrm{a}$, 1920b and others), De Lotto (1958, 1967a, 1967b, 1969 and others), Munting (1965, 1973, 1977 and others), Millar (2002) and some other authors, the reader can find comprehensive analysis of the fauna in those publications. In November 2016 the second author collected several species of scale insects in the Cape Region, three of which (two from the family Pseudococcidae and one - from Coccidae) are new for science and will be described below.

\section{Material and methods}

The specimens were collected on the west bank of the lower Palmiet River (Western Cape, South Africa) (Fig. 1). Live insects were removed, together with a piece of plant material and transferred to Eppendorf tubes containing $96 \%$ ethanol. A method of preparation of the Canada balsam slides can be found, for example, in Danzig \& Gavrilov-Zimin (2014). 
All material is deposited in the Zoological Institute of the Russian Academy of Sciences (ZIN RAS) (St. Petersburg, Russia), excluding the holotypes of the new species which will be sent to the ARC-Plant Protection Research Institute, Pretoria. The numbers with "K" refer to the unique collection numbers of both ethanol material and Canada balsam slides.

\section{Results}

\section{Systematic part}

Order Homoptera auct., non Latreille, 1810

Family Pseudococcidae Cockerell, 1905

Subfamily Phenacoccinae Šulc, 1944

Genus Coccidohystrix Lindinger, 1943

Coccidohystrix daedalea Gavrilov-Zimin sp. nov.

urn:1sid:zoobank.org:act:8E66C991-940A-43B7-84B2-DDD1EA1C8803

Fig. 2

\section{Etymology}

The species name is based on the Latin word "daedaleus", meaning ornamented or patterned, referring to the groups of wax glands on the dorsum.

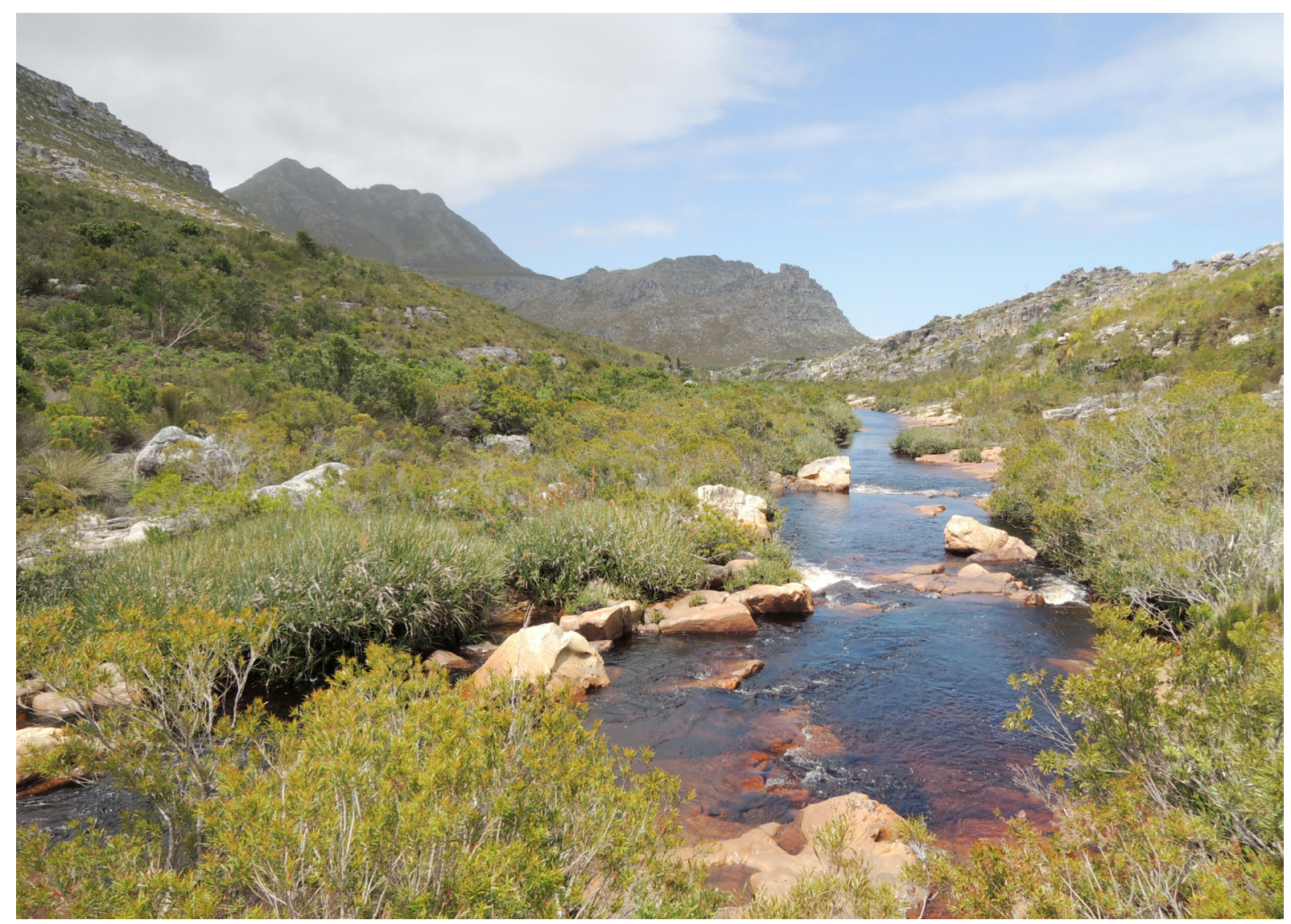

Fig. 1. South Africa, Western Cape Prov., banks of the Lower Palmiet River, the type locality of the new species. 


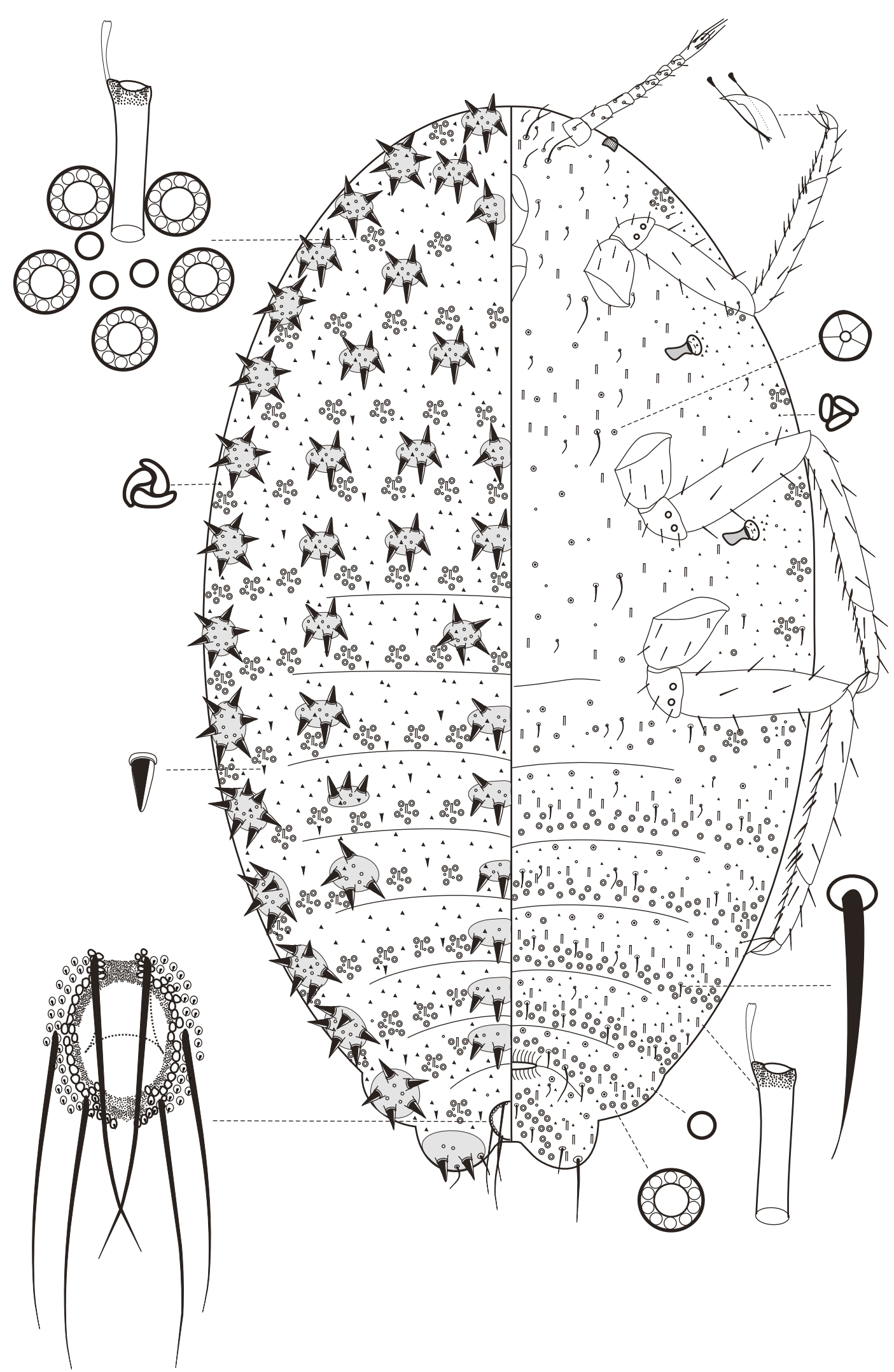

Fig. 2. Coccidohystrix daedalea Gavrilov-Zimin sp. nov., adult female, holotype. 


\section{Material examined}

Holotype

SOUTH AFRICA: +, Western Cape Prov., near Lower Palmiet River, $34^{\circ} 19.713$ S, $18^{\circ} 58.841 \mathrm{E}$, on flowers of Felicia sp. (Asteraceae), 7 Nov. 2016, S. Neser and Ph.E. Chetverikov leg. (K 1323).

\section{Paratypes}

SOUTH AFRICA: 3 우, with the same collection data, each on a separate slide. All slides with the same collecting number as holotype; there are no separate numbers for each slide.

\section{Description}

\section{Female}

Body elongate oval, up to $2 \mathrm{~mm}$ long. Antennae 8-segmented. Legs well developed, without translucent pores; claw with a denticle. Anal apparatus complicated, with inner row of pores, double outer row of spinulae and 6 setae, about two time as long as diameter of anal ring. Ostioles and circuli absent. Multilocular pores numerous, forming groups (each group includes 3-7, mostly 5 multilocular pores, one tubular duct and several simple pores) on all tergites and in marginal zone of thoracic sternites and transverse bands on abdominal sternites. Quinquelocular pores scattered throughout medial zone of venter. Trilocular pores scattered on entire body surface, excluding medial zone of thoracic sternites; dorsal trilocular pores slightly larger than ventral ones; occasional trilocular pores present also in mamelons. Simple discoidal pores scattered on venter and present in dorsal groups with multilocular pores and tubular ducts. Tubular ducts of one size, about two times as long as diameter of multilocular pore, present in dorsal groups (one duct per group), forming transverse rows on abdominal sternites and scattered on thoracic sternites (Fig. 2). Mamelons each with 3-7 stout thick conical setae, several simple pores and occasional trilocular pores, forming a row along entire body margin, a row along midline of dorsum and additionally present in submarginal and submedial zones of thoracic and anterior abdominal tergites (Fig. 2). Minute conical setae sparsely scattered on dorsal surface of body.

\section{Males and larvae \\ Unknown.}

\section{Comments}

The new species differs from all congeners in the presence of numerous dorsal groups of wax glands (each with 3-7 multilocular pores, one tubular duct and several simple pores). See the modern identification key for the world fauna of the genus in Gavrilov-Zimin (2016).

All collected females were very young, before oviposition and without eggs inside the body.

Subfamily Pseudococcinae Šulc, 1944

Genus Mirococcopsis Borchsenius, 1948

Mirococcopsis ptilura Gavrilov-Zimin sp. nov. urn:Isid:zoobank.org:act:0639ED7E-435F-4485-BFD5-DD254A49C172

Fig. 3

\section{Etymology}

The species epithet is derived from the ancient Greek words " $\pi \tau i$ i $\lambda \mathrm{ov"} \mathrm{-} \mathrm{downiness} \mathrm{(Latin} \mathrm{prefix} \mathrm{ptil-),}$ and "oủpó" -tail. 


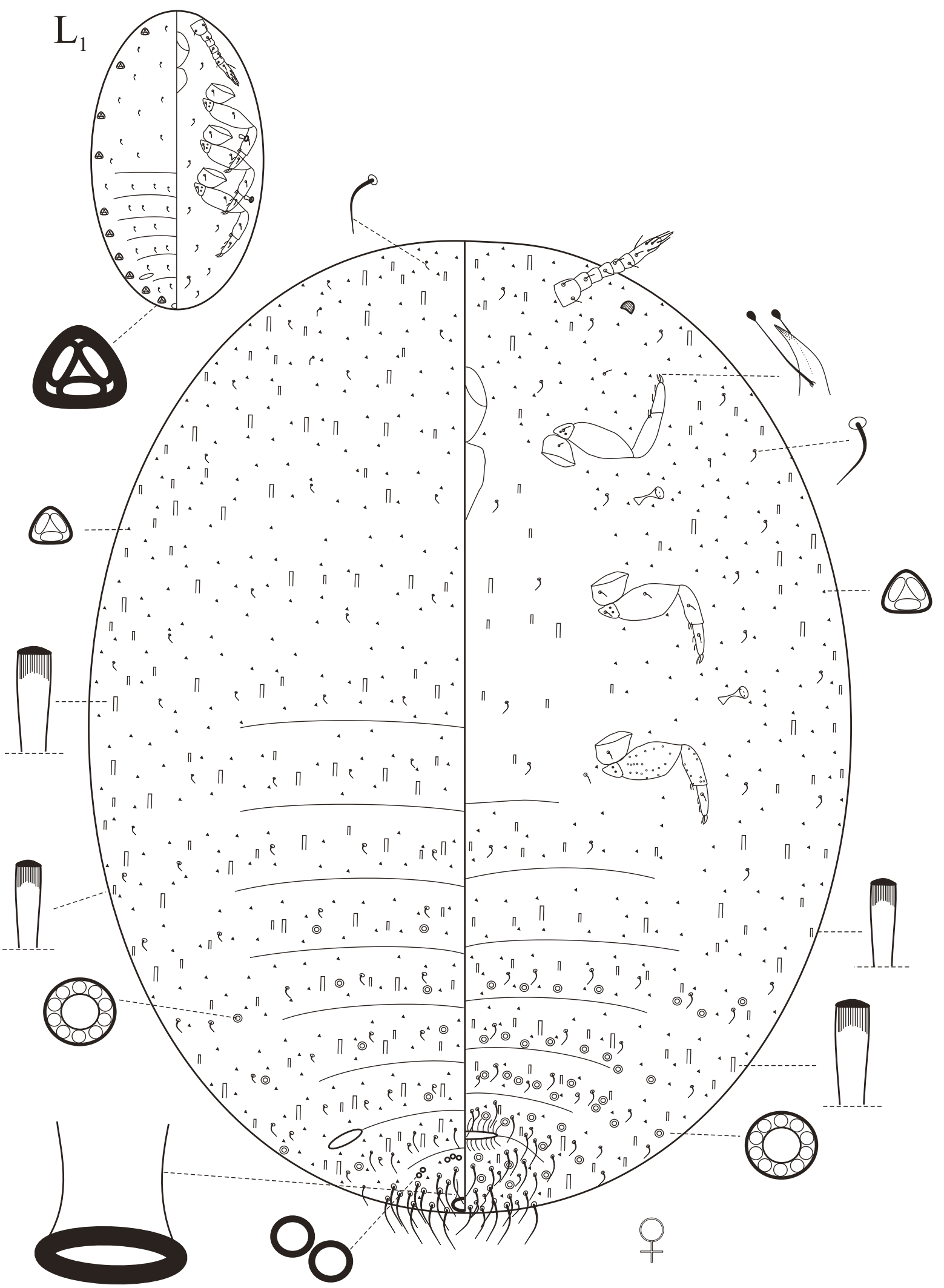

Fig. 3. Mirococcopsis ptilura Gavrilov-Zimin sp. nov., adult female (holotype) and primolarva $\left(\mathrm{L}_{1}\right)$. 


\title{
Material examined
}

\section{Holotype}

SOUTH AFRICA: +, Western Cape Prov., near Lower Palmiet River, $34^{\circ} 19.713$ S, $18^{\circ} 58.841$ E, on twigs of Aspalathus sp. (Fabaceae), 7 Nov. 2016, S. Neser and Ph.E. Chetverikov leg. (K 1326).

\section{Paratypes}

SOUTH AFRICA: 3 q + , with the same collection data, each on a separate slide.

\section{Description}

\section{Female}

Body broadly oval or almost round, up to $2 \mathrm{~mm}$ long, enclosed in soft wax sac. Antennae 7-segmented. Legs shortened, middle and hind legs with enlarged coxae; hind femurs and tibiae with translucent pores; claw without a denticle. Ostioles represented by posterior pair only. Circulus absent. Anal apparatus strongly simplified and includes only sclerotized ring and short internal anal tube. Multilocular pores forming sparse transverse rows on posterior abdominal tergites and sternites. Trilocular pores sparsely scattered on all body surface excluding medial zone of thoracic sternites. Simple discoidal pores with heavily sclerotized rim forming groups of $2-3$ pores on posterior abdominal tergite. Simple tubular ducts of two sizes: larger ducts about two times as long as diameter of multilocular pore; smaller ducts slightly longer than diameter of multilocular pore; both types of ducts scattered over entire body surface, but larger ducts more numerous in marginal zone of body on both sides. Short and thin flagellate setae scattered on entire body surface; setae on anal segment significantly longer.

Males

Unknown.

\section{Primolarvae}

Primolarvae were observed inside the female bodies (ovoviviparity) show a simplified anal apparatus and unusual huge trilocular pores about 2 times as large as the usual pores and forming a row along the body margin (see Fig. 3).

\section{Comments}

It is difficult to clearly define the taxonomic position of this species. In view of the total reduction of the cerarii, a claw without a denticle and the simplified anal apparatus the species seems to be related to species of the Palaearctic genus Mirococcopsis Borchsenius, 1948, especially to M. sphaerica (Balachowsky, 1930) which is known from Tunisia. The new species differs from M. sphaerica in the absence of fungiform ducts, the presence of translucent pores on the hind legs and the structure of the anal apparatus with a closed anal ring lacking any setae (in contrast to an open-ended anal ring with 6 small setae in $M$. sphaerica). See the modern identification key for the genus in Danzig \& Gavrilov-Zimin (2015).

\author{
Family Coccidae Fallén, 1814 \\ Subfamily Cardiococcinae Hodgson, 1994 \\ Genus Cryptinglisia Cockerell, 1900 \\ Cryptinglisia millari Gavrilov-Zimin sp. nov. \\ urn:1sid:zoobank.org:act:102FC54D-EF8C-4AA6-88ED-748E4C2726EF
}

Figs 4-5

\section{Etymology}

The species is named in honour of Dr. Ian Millar in view of his long term studies of South African scale insects. 


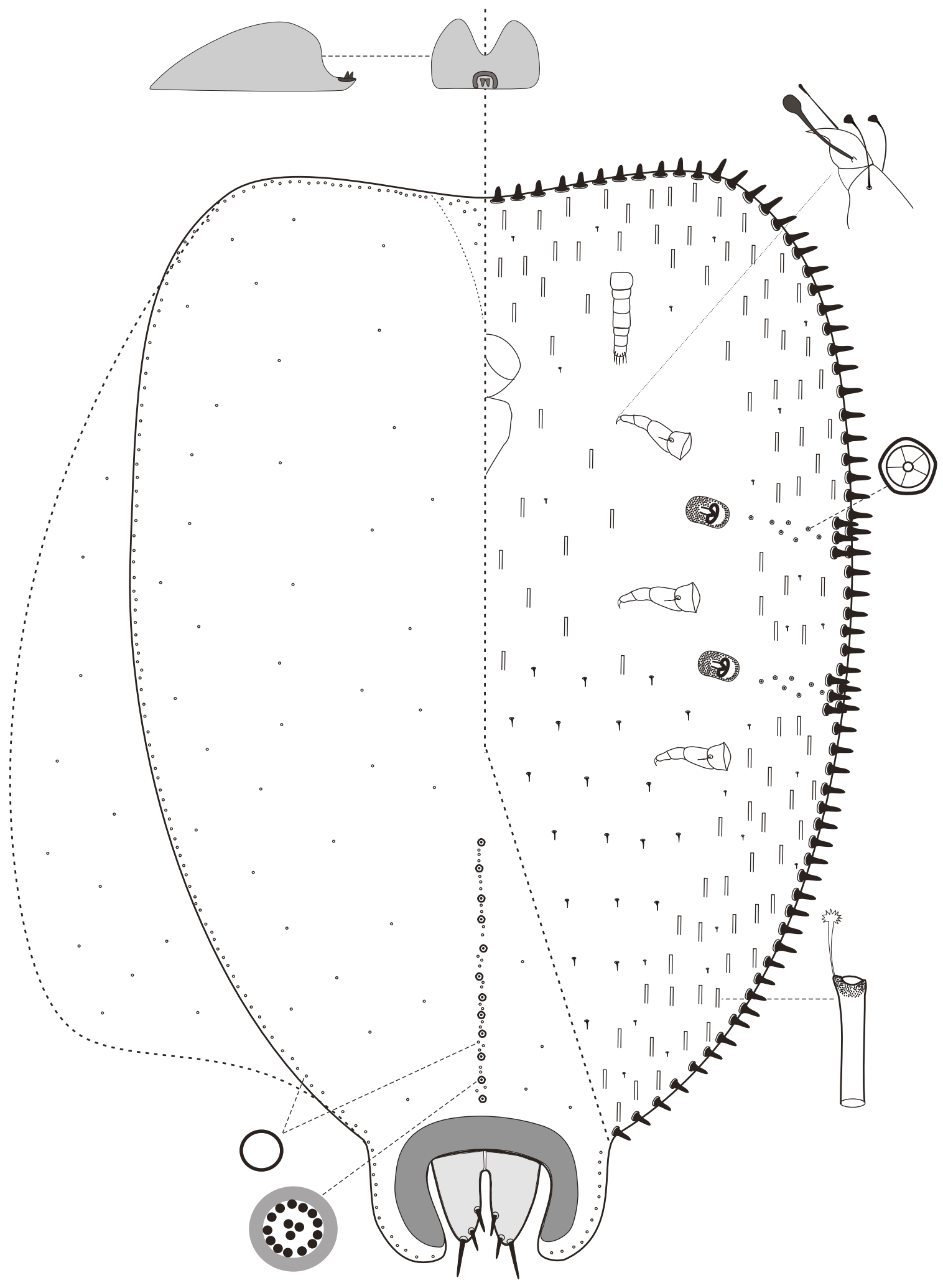

Fig. 4. Cryptinglisia millari Gavrilov-Zimin sp. nov., adult female, holotype. 


\section{Material examined}

\section{Holotype}

SOUTH AFRICA: $q$ in black circle, Western Cape Prov., near Lower Palmiet River, $34^{\circ} 19.713$ S, $18^{\circ} 58.841$ E, on twigs of Passerina sp. (Thymelaeaceae), 9 Nov. 2016, S. Neser and Ph.E. Chetverikov leg. (K 1320).

\section{Paratypes}

SOUTH AFRICA: 1 , on the same slide and 6 우 on 3 other slides, all with the same collection data.

\section{Description}

\section{Female}

Body in life flat on venter and with two symmetric humps on dorsum (Fig. 5), covered with shining wax. Female on slide piriform, about $1.5 \mathrm{~mm}$ long. Antennae short, 7-8 segmented. Legs very short, with partly reduced segments; claw without denticle; claw digitules on each claw asymmetric, one significantly larger than other (Fig. 4). Multilocular pores absent. Quinquelocular pores present on venter in stigmatic furrows. Preopercular pores forming row on dorsal side of abdomen along midline. Simple discoidal pores present along midline of abdominal dorsum together with compound pores. Tubular ducts of about same size forming wide marginal band on venter and also scattered on medial zone of thoracic sternites. Marginal conical setae short and stout. Stigmatic clefts marked each by 3 additional conical setae similar in size with marginal setae. Minute pointed setae sparsely scattered on venter.

\section{Males and larvae}

Unknown.

\section{Comments}

The genus Cryptinglisia Cockerell, 1900 comprised until now 3 African species (all were described from South Africa). The new species seems to be most similar with C. elytropappi (Brain, 1920), but, according to the redescription and illustration of De Lotto (1967b), the latter species has only one stigmatic seta per stigmatic cleft (in contrast to 3 setae in addition to an uninterrupted row of marginal setae in C. millari sp. nov.), symmetric claw digitules (strongly asymmetric in C. millari sp. nov.) and does not have rows of simple pores along the margin and along the midline (see the Key below). The new species is ovoviviparous with fully developed larvae inside the mother's body.
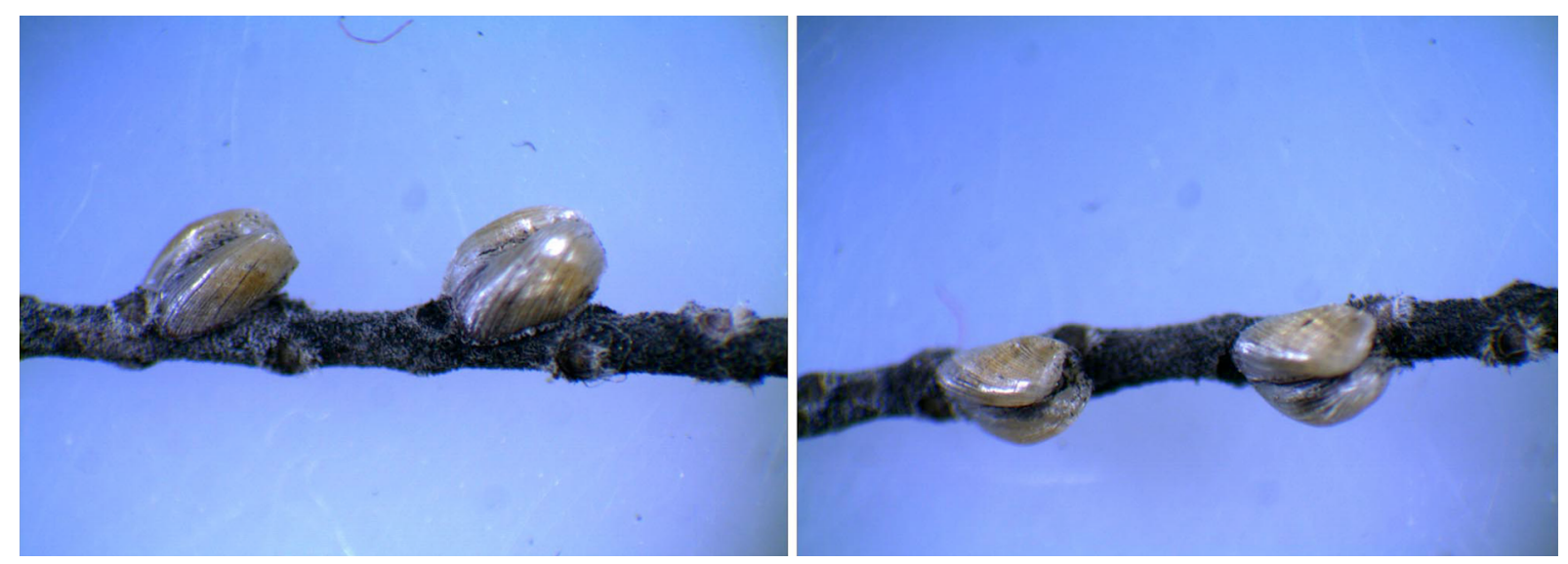

Fig. 5. Cryptinglisia millari Gavrilov-Zimin sp. nov., adult females in life. 


\section{Key to African species of the genus Cryptinglisia}

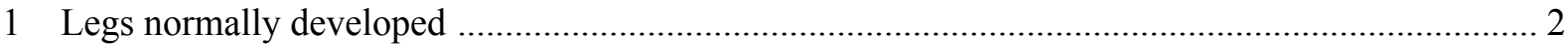

- Legs vestigial, with partly reduced segments …………………………………………………... 3

2 Stigmatic setae significantly longer than marginal setae ................... C. lounsburyi Cockerell, 1900

- Stigmatic setae similar in length with marginal setae .................................. . zizyphi (Brain, 1920)

3 One stigmatic seta present in each stigmatic cleft; claw digitules symmetric; rows of simple pores absent along body margin and along midline

C. elytropappi (Brain, 1920)

- Three stigmatic setae present in each stigmatic cleft in addition to uninterrupted row of marginal setae; claw digitules strongly asymmetric (Fig. 4); row of simple pores present along body margin and along midline

C. millari Gavrilov-Zimin sp. nov.

\section{Discussion}

The newly described species belong to two major scale insect families, Pseudococcidae and Coccidae, which each comprise about 100 species in the fauna of South Africa. Both these families contain numerous endemic genera and species in the fauna of South Africa and in the Cape region in particular (see the works of Brain 1915, 1918, 1919, 1920a, 1920b; De Lotto 1958, 1967a, 1967b, 1969; Millar 2002). Thus, South African Pseudococcidae comprise at least 13 genera and 68 species recorded only from this country (Millar 2002) and most of these species live on the aerial parts of plants. On the other hand, mealybugs as a whole are a group adapted to hypogeal life on roots of host plants and a lot of new mealybug species may probably be discovered in the future following targeted collection from the underground parts of bushes, herbs and grasses, especially in such Mediterranean-like biotopes as in Fig. 1. In the family Coccidae there are 6 genera and 45 species endemic to South Africa according to our check of 100 species listed for the country in the ScaleNet database (García Morales et al. 2016). These numbers are probably very close to the real numbers of the natural diversity, because soft scales usually openly live on leaves, branches and twigs of trees and bushes, have a comparatively large body size and are relatively easy to collect. We supposed after the long-term works of C.K Brain and G. De Lotto (cited above) that the soft scales of South Africa could be considered to be well studied. The discovery of the new species, Cryptinglisia millari sp. nov., seems to be rather occasional and exclusive. The unusually small (for soft scales) size of the body of the females of this species was probably a reason why it was neglected in previous studies. The second author of this paper was able to find it only during his stereomicroscopic studies of Eriophyoidea mites, which live on twigs of Passerina sp.

\section{Acknowledgements}

We are grateful to Dr. S. Neser (University of Pretoria, South Africa) and Dr. C. Craemer (ARC-Plant Protection Research Institute, South Africa) for their help in collecting coccids, host-plant identification and getting official permission for collecting insects in the Western Cape Province. The authors thank Dr Demian Kondo and Dr Ian Millar for useful comments on the taxonomic characters of Cryptinglisia millari sp. nov., Dr Dmitrii A. Gapon for the consultations in the Latin and Greek grammar, Dr Danièle Matile-Ferrero and Dr Giuseppina Pellizzari for reviewing the manuscript. The work was performed in the context of the state research project no. 01201351189 of the Zoological Institute of the Russian Academy of Sciences.

\section{References}

Brain C.K. 1915. The Coccidae of South Africa. Transactions of the Royal Society of South Africa 5: 65-194.

Brain C.K. 1918. The Coccidae of South Africa - II. Bulletin of Entomological Research 9: 107-139. 
Brain C.K. 1919. The Coccidae of South Africa - III. Bulletin of Entomological Research 9: 197-239.

Brain C.K. 1920a. The Coccidae of South Africa - IV. Bulletin of Entomological Research 10: 95-128.

Brain C.K. 1920b. The Coccidae of South Africa - V. Bulletin of Entomological Research 11: 1-41.

Danzig E.M. \& Gavrilov-Zimin I.A. 2014. Palaearctic mealybugs (Homoptera: Coccinea: Pseudococcidae). Part 1. Subfamily Phenacoccinae. Fauna of Russia and neighbouring countries. New series, No. 148. Insecta: Hemiptera: Arthroidignatha. ZIN RAS, St Petersburg.

Danzig E.M. \& Gavrilov-Zimin I.A. 2015. Palaearctic mealybugs (Homoptera: Coccinea: Pseudococcidae). Part 2. Subfamily Pseudococcinae. Fauna of Russia and neighbouring countries. New series, No. 149. Insecta: Hemiptera: Arthroidignatha. ZIN RAS, St Petersburg.

De Lotto G. 1958. The Pseudoccoidae (Hom.: Coccoidea) described by C.K. Brain from South Africa. Bulletin of the British Museum (Natural History) Entomology, Supplement 7: 79-120.

De Lotto G. 1967a. The mealybugs of South Africa (Homoptera: Pseudococcidae), I. Entomology Memoirs, Department of Agricultural Technical Services, Republic of South Africa. Pretoria 12: 1-28.

De Lotto G. 1967b. The soft scales (Homoptera: Coccidae) of South Africa. I. South African Journal of Agricultural Sciences 10: 781-810.

De Lotto G. 1969. The mealybugs of South Africa (Homoptera: Pseudococcidae), II. Entomology Memoirs, Department of Agricultural Technical Services, Republic of South Africa. Pretoria 20: 1-30.

García Morales M., Denno B.D., Miller D.R., Miller G.L., Ben-Dov Y. \& Hardy N.B. 2016. ScaleNet: A literature-based model of scale insect biology and systematics. Database.

https://doi.org/10.1093/database/bav118. http://scalenet.info

Gavrilov-Zimin I.A. 2016. A new species of the genus Coccidohystrix (Homoptera: Coccinea: Pseudococcidae) from Madagascar. Tropical Zoology 29 (4): 184-188.

https://doi.org/10.1080/03946975.2016.1235421

Millar I.M. 2002. Mealybug genera (Hemiptera: Pseudococcidae) of South Africa: identification and review. African Entomology 10 (2): 185-233.

Munting J. 1965. Lac insects (Homoptera: Lacciferidae) from South Africa. Journal of the Entomological Society of Southern Africa 28: 32-43.

Munting J. 1973. Redescription of some Diaspididae (Homoptera: Coccoidea) from Southern Africa. Phytophylactica 5: 13-22.

Munting J. 1977. On the genera Aulacaspis, Duplachionaspis and Ledaspis from southern Africa (Homoptera: Diaspididae). Entomology Memoirs, Department of Agricultural Technical Services, Republic of South Africa. Pretoria 46: 1-34.

Manuscript received: 23 February 2017

Manuscript acepted: 15 May 2017

Published on: 14 November 2017

Topic editor: Gavin Broad

Desk editor: Pepe Fernández

Printed versions of all papers are also deposited in the libraries of the institutes that are members of the EJT consortium: Muséum national d'Histoire naturelle, Paris, France; Botanic Garden Meise, Belgium; 
Royal Museum for Central Africa, Tervuren, Belgium; Natural History Museum, London, United Kingdom; Royal Belgian Institute of Natural Sciences, Brussels, Belgium; Natural History Museum of Denmark, Copenhagen, Denmark; Naturalis Biodiversity Center, Leiden, the Netherlands; Museo Nacional de Ciencias Naturales-CSIC, Madrid, Spain; Real Jardín Botánico de Madrid CSIC, Spain. 